\title{
Effects of poultry manure on soil infiltration, organic matter contents and maize performance on two contrasting degraded alfisols in southwestern Nigeria
}

\author{
Adebayo. J. Adeyemo ${ }^{1} \cdot$ Omowunmi O. Akingbola ${ }^{1} \cdot$ Stephen O. Ojeniyi ${ }^{1}$
}

Received: 27 August 2018 / Accepted: 27 May 2019 / Published online: 1 June 2019

(c) The Author(s) 2019

\begin{abstract}
Purpose This research work described the effect of organic waste (poultry manure) on soil cumulative infiltration rate (CIR), soil organic matter (SOM), and maize performance on two contrasting alfisols of southwestern Nigeria.

Methods Six treatments of poultry manure were applied in split at $0 \mathrm{Mg} / \mathrm{ha}, 2 \mathrm{Mg} / \mathrm{ha}, 4 \mathrm{Mg} / \mathrm{ha}, 6 \mathrm{Mg} / \mathrm{ha}, 8 \mathrm{Mg} / \mathrm{ha}$, and $10 \mathrm{Mg} / \mathrm{ha}$, in replicate under a completely randomized design to clay loam (CL) and sandy clay loam (SCL) soils, at 3, 6, 9, and 12 weeks after the initial application.

Results The results showed significant increases $(P<0.05)$ in CIR, SOM, and maize performance compared to the control in both soils. Poultry manure at $10 \mathrm{Mg} /$ ha recorded the highest SOM which was significantly $(P<0.05)$ different from other application rates in both soils. The mean values for SOM in SCL were between 0.67 and $3.75 \%$ for $0 \mathrm{Mg} / \mathrm{ha}$ and $10 \mathrm{Mg} / \mathrm{ha}$, while the mean values recorded for CL were between 0.80 and $4.35 \%$ at $0 \mathrm{Mg} / \mathrm{ha}$ and $10 \mathrm{Mg} / \mathrm{ha}$. Poultry manure reduced CIR in the SCL, but improved CIR with increasing rates on CL. Poultry manure at 4-10 Mg/ha increased the maize shoot biomass significantly $(P<0.05)$. However, the application rate of $6 \mathrm{Mg} / \mathrm{ha}$ manure recorded the highest fresh shoot biomass, while $8 \mathrm{Mg} /$ ha increased dry shoot biomass in both soils.

Conclusion This study indicated that poultry manure applied at $10 \mathrm{Mg} / \mathrm{ha}$ gave the best results in improving CIR, SOM, and maize performance on different soil types.
\end{abstract}

Keywords Maize (Zea mays L.) · Soil water infiltration · Organic matter · Alfisol · Poultry manure

\section{Introduction}

Maize (Zea mays L.) is a cereal crop grown mainly in a developing country like Nigeria which provides a source of income to the large population of small holder farmers. No cereal crop is produced annually more than maize in the country due to its high demand from consumers and its great nutritional value. Maize contains great nutritional value as depicted by its richness in vitamins $\mathrm{A}, \mathrm{C}$ and $\mathrm{E}$,

Adebayo. J. Adeyemo

ajadeyemo@futa.edu.ng

Omowunmi O. Akingbola

ooakingbola@futa.edu.ng

Stephen O. Ojeniyi

soojeniyi@futa.edu.ng

1 Department of Crop, Soil and Pest Management, The Federal University of Technology, Akure, Ondo State, Nigeria carbohydrates, essential minerals, starch, protein, oil, fiber, sugar, and ash contents in respective amount of $72 \%, 10 \%$, $4.8 \%, 8.5 \%, 3 \%$, and $1.7 \%$ (Chaudhary 1993). It is also rich in dietary fiber and calories which provide a good source of energy, a staple food for humans, livestock, and an important raw material for many industrial products (Agbogidi et al. 2007). Maize yield in the tropical regions of SubSahara Africa (SSA) has been declining gradually due to the degrading nature of soils in these zones. Lal (1986) described the soils in these zone to be of suborder of alfisols, oxisols, ultisols, and inceptisols which contain low activity clays; they are considered as soils with low soil organic carbon (SOC), low CEC, high nutrient leaching; poor aggregate stability having susceptibility to high erosion, crusting and compaction caused by continuous cropping, pollution from excessive fertilizer application, heavy usage of farm machinery, and other factors. Agricultural waste (organic amendments) such as poultry manure has been proposed to be a good method, environmental friendly, and cost effective for 
improving physical and chemical status of degraded humic tropical alfisols. Poultry manure is an exceptional source of organic fertilizer which contains high percentage of nitrogen, phosphorus, potassium and other important nutrients readily available for plant uptake as compared to other organic sources (Mohamed et al. 2010; Garg and Bahla 2008). It improves the physical characteristics and conditions of the soil and improves the nutrient uptake and crop productivity (Ojeniyi et al. 2013; Mbah and Nnej 2011; Tisdall and Oades 1993). The addition of organic amendments such as poultry manure improves soil properties by improving organic matter contents of the soil, which has a stimulatory effect on the structure and aggregate stability, thereby improving the aeration, buffering of soil reaction, water holding capacity, cation exchange capacity, and microbial activities (Bauer and Black 1992). Esu (2005), in his findings on Nigerian soils observed that organic matter serves as a binding agent of soil particles into aggregates, thus promoting a good soil structure which results in good drainage, while Pagliai et al. (2004) added that the improvement of soil structure can be achieved by organic fertilizer application through the protection of the soil surface and the maintenance of continuous transmission pores through the profile. Poultry manure with high proportion of organic carbon content improves organic matter of the soil and retains substantial amounts of soil water, and this subsequently increases the water content of soil upon application of the manure (Mohamed et al. 2010). Organic matter of the soil influences the degree of aggregation, total porosity, and hydraulic conductivity of heavy soils positively (Anikwe 2000). Several research have also alluded to the fact that addition of poultry manure as a soil conditioner reduced the bulk density of the soil (Brye et al. 2004; Martens and Frankenberger 1992). This is due to the inherent low bulk density of organic materials used which results in lower soil bulk density. Poultry manure can also improve soil water infiltration rates which serve as a good conditioner for soil's potential to allow water movement in both lateral and horizontal gradients into and through the soil profile (Zerihun et al. 1996; Oyonarte et al. 2002). However, poor soil aeration that leads to plant root malfunctioning and development also reduced nutrient cycling by micro and macro organisms as a result of restricted infiltration rate and subsequent ponding of water on the soil surface (Lowery et al. 1996). Ponding and soil saturation decreases soil strength when the total soil pore spaces are completely filled with water, and ultimately destroys the structure of the soil, dispassion of soil particles, thereby making the soil susceptible to erosion. An optimum soil infiltration rate is undoubtedly considered for growth of plant and the environment. Therefore, desirable manipulation of the soil can optimize higher infiltration and water storage as allowed by a specific soil type (USDA 1998). Organic amendments have been widely reported by many researchers to have positive impacts on soil physical characteristics, especially hydrologic and hydraulic properties such as hydraulic conductivity and infiltration rate (Eusufzai and Fujii 2012; Tisdall and Oades 1993; Martens and Frankenberger 1992). There was a reduction in water movement as observed by Mubarak et al. (2009) in sandy soils when organic residues were added, while Martens and Frankenberger (1992) found that additions of poultry manure to soil resulted in significantly increased (18\%) cumulative water infiltration rates compared to the control. Other factors such as texture, crust, compaction, aggregation, structure, water content, pores, and microorganisms could also affect soil water infiltration rates negatively. Many researchers have previously focused on the studies of effect of poultry manure on soil chemical characteristics and crop yield whereas the literature has been silent on its usefulness in improving physically degraded soil types especially in the tropical alfisols of Sub-Sahara Africa.

\section{Purpose of the experiment}

The following research questions would be painstakingly answered from the experiment: (1) what are the poultry manure's impacts on soil water infiltration rates, organic matter contents, and maize yield on to physically degraded two contrasting alfisol? (2) What is the optimal poultry manure application rate for improving physical properties of degraded tropical alfisols and maize yield?

\section{Materials and methods}

\section{Description of the study area}

The field experiments were located in Akure in the humid rainforest zone of southwest Nigeria. Two experimental sites with different soil textural and colloidal properties (clay loam and sandy clay loam) at the teaching and research farm of the Federal University of Technology, Akure were used in early rainy season of 2017. The soil at the experimental sites belongs to the soil order alfisol classified as clayey skeletal oxic-paleustaif (Soil Survey Staff 1999). Akure lies between Lat. $7^{\circ} 20^{\prime} \mathrm{N}$ and Long. $5^{\circ} 30^{\prime} \mathrm{E}$ with a bimodal rainfall pattern consisting of long rainy season usually between March and July and a short rainy season extending from September to early November, after a short dry spell in August and a longer dry period from December to February. The annual average precipitation is between 1000 and $2060 \mathrm{~mm}$, while the annual average temperature of the area is between 29 and $37{ }^{\circ} \mathrm{C}$ as presented in Table 1. 
Table 1 Monthly rainfall and temperature data during experiment period at Akure

\begin{tabular}{llll}
\hline Months & Rainfall $(\mathrm{mm})$ & $\begin{array}{l}\text { Temperature } \\
\left(0{ }^{\circ} \mathrm{C}\right)\end{array}$ & Humidity $(\%)$ \\
\hline May & 166.60 & 32.6 & 71.10 \\
June & 191.63 & 30.9 & 75.70 \\
July & 203.20 & 29.2 & 82.7 \\
August & 192.90 & 28.8 & 85.1 \\
\hline
\end{tabular}

Agro-climatological and Ecological Project, Ondo State Ministry of Agriculture

\section{Sample collection and preparation}

Soil samples from the study area were analyzed prior to treatment application after collection with the aid of auger from each experimental sites. Bulked soil sample collected at a depth of $0-15 \mathrm{~cm}$ was analyzed for physical properties and organic matter content. Fifty-four (54) composite soil samples were collected later after poultry manure application at a depth of $0-15 \mathrm{~cm}$ and analyzed for physical properties and organic matter contents periodically throughout the experiment.

\section{Experimental design and land preparation}

The experiment was laid in randomized block design (RBD) with 6 plots and 3 replicates, making a total of 18 plots. Each plot size was $2 \mathrm{~m} \times 2 \mathrm{~m}\left(4 \mathrm{~m}^{2}\right)$ and buffer zone between plots and blocks was $1 \mathrm{~m}$. Maize seeds were collected from a government certified seed bank in the country and sown into plots at a spacing of $75 \mathrm{~cm} \times 25 \mathrm{~cm}$.

\section{Experimental procedure}

Six treatments of moderately weathered poultry manure were applied at $0 \mathrm{Mg} / \mathrm{ha}, 2 \mathrm{Mg} / \mathrm{ha}, 4 \mathrm{Mg} / \mathrm{ha}, 6 \mathrm{Mg} / \mathrm{ha}, 8 \mathrm{Mg} /$ ha, and $10 \mathrm{Mg} / \mathrm{ha}$ by broadcasting and worked into the soil with hoes and shovels at 2 weeks before planting, the application was repeated at 4 weeks and 8 weeks from the initial application (WAIA).

\section{Determination of soil physical properties}

\section{Infiltration rate}

The method employed was that of the falling head condition, whereby water is added to reach a target level in the infiltrometer after which the subsequent decline in water level was recorded as infiltration. The infiltrometer was driven $5 \mathrm{~cm}$ into the soil for a period of $30 \mathrm{~min}$. The vertical movement of water into the soil through the ring was recorded at 2 min interval on $3,6,9$, and 12 weeks after the application of poultry manure to the soil. Infiltration rate has the dimensions of velocity, $L T^{-1}$, where $L$ is thelength and $T$ is the time. Initial infiltration rate being the amount of water that enters into the soil in the first 2 min of water contact with the soil was derived at 3,6, 9, and 12 weeks after application of poultry manure to the soil in $\mathrm{cm} / \mathrm{h}$ basis, by calculating the horizontal distance in the first 2 min per time taken to move the distance. Basic infiltration rate was derived at 3, 6, 9, and 12 weeks after the application of poultry manure to the soil in $\mathrm{cm} / \mathrm{h}$ basis. This was determined as more water replaced the air in the soil pores; the water from the soil surface infiltrated more slowly and eventually reached a steady rate. Cumulative infiltration rate being the total quantity of water that entered into the soil in $30 \mathrm{~min}$ was derived at $3,6,9$, and 12 weeks after the application of poultry manure to the soil in $\mathrm{cm} / \mathrm{h}$ basis. Volumetric infiltration rate being the volume of water that entered into the soil in a period of $30 \mathrm{~min}$ was derived at 3, 6, 9, and 12 weeks after the application of poultry manure to the soil using the formula

$V / t=\left(\pi r^{2} h\right) / t$,

where $V / t$ is the volumetric infiltration rate (volume of water per time) in $\mathrm{cm}^{3} / \mathrm{h} ; t$ the time in $\mathrm{h} ; r^{2}$ the square of radius of the ring in $\mathrm{cm}^{2} ; h$ the total vertical amount of water that entered into the soil during each procedure in $\mathrm{h}$ basis; $\pi$ is a unit-less constant whose value is 3.143 .

\section{Sorptivity}

Sorptivity being the measure of the ability of the soil to absorb water was derived at 3, 6, 9, and 12 weeks after the application of poultry manure to the soil from cumulative infiltration as function of square root of time for period of $30 \mathrm{~min}$ as described by (Philip 1969):

$S=I t^{1 / 2}$,

where $S$ is the sorptivity, $I$ the cumulative infiltration, $t^{1 / 2}$ is the time square root of time.

\section{Bulk density}

Soil bulk density was determined from oven-dried undistributed core samples collected to the depth of $5 \mathrm{~cm}$ by core method (Blake and Hartge 1986) at 3, 6, 9, and 12 weeks after the application of livestock manure to the soil. A cylindrical metal sampler of $2.5 \mathrm{~cm}$ diameter and $5 \mathrm{~cm}$ long was used to sample undisturbed soil. The soil was then weighed, dried at $105^{\circ} \mathrm{C}$ for 2 days and reweighed. Bulk density was computed as: 


\section{Bulk density $\left(\mathrm{g} / \mathrm{cm}^{3}\right)$ \\ $=$ Mass of oven dried soil $(\mathrm{g}) /$ total volume $\left(\mathrm{cm}^{3}\right)$. \\ Organic matter determination}

The determination of soil organic carbon contents was performed by the modified method of Walkley-Black as described by Nelson and Sommers (1982). Organic carbon values were eventually converted to organic matter by multiplying organic carbon values by 1.724 . This procedure was carried out at $3,6,9$, and 12 weeks after initial application (WAIA) of poultry manure to the soil. Table 2 shows the test soil's initial physical properties before poultry manure application and planting. Results affirm the degraded physical attributes of the test soils and the need for reclamation, while the organic matter of the test soil was also below the critical level of 3\% required for crop optimum production (Ande 2011).

\section{Maize yield parameter}

The yield was estimated by measuring cob weight and dry grain weight of 1000 grains. Harvesting of the shoot materials was performed at 12 WAIA, oven drying for 3 days to constant weight was performed to determine the biomass (dry matter) yield per plant $(\mathrm{g})$. The averages of five plants that were randomly selected and destructively sampled were used as score for each plot. The fresh and oven-dried shoot weights were recorded.

Table 2 Initial soil physical properties and composition of poultry manure used

\begin{tabular}{llll}
\hline Soil properties & Clay loam & Sandy clay loam & Poultry manure \\
\hline Sand (\%) & 22.7 & 67.7 & - \\
Silt (\%) & 40.1 & 11.2 & - \\
Clay (\%) & 37.2 & 21.1 & - \\
Bulk density (g/cm $\left.{ }^{3}\right)$ & 1.51 & 1.47 & - \\
Moisture content (\%) & 20.1 & 12.8 & - \\
Cumulative infiltra- & 15.0 & 18.0 & - \\
$\quad$ tion rate (cm/h) & & & \\
Sorptivity & 0.18 & 0.21 & - \\
Organic matter (\%) & 0.81 & 0.73 & - \\
Organic carbon (\%) & - & - & 27.80 \\
Nitrogen (\%) & - & - & 3.87 \\
Phosphorus (\%) & - & - & 3.40 \\
Potassium (\%) & - & - & 1.90 \\
Calcium (\%) & - & - & 1.40 \\
Magnesium (\%) & - & - & 0.56 \\
C/N & - & - & 7.18 \\
\hline
\end{tabular}

Mean values are presented in this table

\section{Statistical analysis}

All the data collected were subjected to analysis of variance as described by Snedecor and Cochran (1967). Duncan's multiple range test (Duncan 1955) was used to separate significant differences in the means of the treatments.

\section{Results and discussion}

\section{Initial soil physical status of the two contrasting alfisols}

The soil physical characteristics at the sites of the experiment are described in Table 2. The textures of the soils were clay loam and sandy clay loam. The bulk density of the soils ranged from 1.47 to $1.51 \mathrm{~g} / \mathrm{cm}^{3}$. The values recorded for the moisture, sorptivity, and organic matter content in clay loam were higher compared with the sandy clay loam except in cumulative infiltration rate that recorded lower value. The poultry manure had $27.8 \%$ organic carbon, $3.87 \% \mathrm{~N}, 3.4 \% \mathrm{P}$, $1.97 \% \mathrm{~K}, 1.4 \% \mathrm{Ca}, 0.56 \% \mathrm{Mg}$, and the $\mathrm{C} / \mathrm{N}$ 7.18. (Table 2). Hence, it was our expectation that application of livestock manure would improve the physical status, especially the soil infiltration, the performance, and the grain yield of maize.

\section{Soil infiltration rate as affected by poultry manure application rates}

Poultry manure application effect on CIR of the different study soil types is presented in Table 3 . At the 3 and 6 WAIA period of determination, poultry manure had no significant $(P>0.05)$ effect on infiltration patterns in both soil types. However, during these periods, poultry manure application at $10 \mathrm{Mg} / \mathrm{ha}$ reduced CIR in the SCL from 19.43 to 18.87 $\mathrm{cm} / \mathrm{h}$ and 20.07 to $18.63 \mathrm{~cm} / \mathrm{h}$ representing reduction of $2.88 \%$ and $7.17 \%$; while on the other hand, increasing rate of poultry manure application improved CIR on CL from 11.60 to $13.80 \mathrm{~cm} / \mathrm{h}$ and 13.00 to $15.73 \mathrm{~cm} / \mathrm{h}$ representing an increase of 18.96 and $21 \%$ at 3 and 6 WAIA, respectively, over the control. Also, poultry manure improved the infiltration rate linearly in the CL soil type especially at $6-10 \mathrm{Mg} / \mathrm{ha}$ rate, while the steady increase in application rate in SCL soil type from 6 to $10 \mathrm{Mg} / \mathrm{ha}$ reduced the infiltration rate. This decline can be adduced to the formation of slurry in the presence of water which could reduce infiltration rate; this was also corroborated by Haraldsen and Sveistrup (1994). Application of cattle manure at the rate of $30 \mathrm{t} / \mathrm{ha}$ was reported by Jiao et al. (2006) to have increased water stable aggregates significantly in sandy soil. This implied an improvement in the soil structural stability and subsequent progressive effects on water retention capacity. 
Table 3 Infiltration rate as affected by poultry manure application on two contrasting alfisols between 3 and 12 weeks after initial application

\begin{tabular}{|c|c|c|c|c|c|c|c|c|}
\hline \multirow{3}{*}{$\begin{array}{l}\text { Poultry } \\
\text { manure }(\mathrm{Mg} / \\
\text { ha) }\end{array}$} & \multicolumn{8}{|c|}{ Cumulative infiltration rate $(\mathrm{cm} / \mathrm{h})$} \\
\hline & \multicolumn{4}{|c|}{ Clay loam } & \multicolumn{4}{|c|}{ Sandy clay loam } \\
\hline & 3 WAIA & 6 WAIA & 9 WAIA & 12 WAIA & 3 WAIA & 6 WAIA & 9 WAIA & 12 WAIA \\
\hline 0 & $11.60 \mathrm{a}$ & $13.00 \mathrm{a}$ & $13.70 \mathrm{~b}$ & $10.70 \mathrm{~b}$ & $19.43 \mathrm{a}$ & $20.07 \mathrm{a}$ & $21.77 \mathrm{a}$ & $23.57 \mathrm{a}$ \\
\hline 2 & $11.60 \mathrm{a}$ & $13.00 \mathrm{a}$ & $14.33 \mathrm{ab}$ & $14.80 \mathrm{a}$ & $18.53 \mathrm{a}$ & $19.13 \mathrm{a}$ & $21.63 \mathrm{a}$ & $22.87 \mathrm{ab}$ \\
\hline 4 & $12.10 \mathrm{a}$ & $13.50 \mathrm{a}$ & $14.97 \mathrm{ab}$ & $15.33 \mathrm{a}$ & $20.10 \mathrm{a}$ & $18.60 \mathrm{a}$ & $21.27 \mathrm{a}$ & $22.60 \mathrm{ab}$ \\
\hline 6 & $13.27 \mathrm{a}$ & $14.80 \mathrm{a}$ & $15.17 \mathrm{ab}$ & $16.37 \mathrm{a}$ & $19.50 \mathrm{a}$ & $18.53 \mathrm{a}$ & $19.80 \mathrm{ab}$ & $20.53 b c$ \\
\hline 8 & $13.47 \mathrm{a}$ & $15.00 \mathrm{a}$ & $15.77 \mathrm{ab}$ & $16.37 \mathrm{a}$ & $18.30 \mathrm{a}$ & $18.67 \mathrm{a}$ & $19.27 \mathrm{ab}$ & $20.00 \mathrm{c}$ \\
\hline 10 & $13.80 \mathrm{a}$ & $15.73 \mathrm{a}$ & $16.33 \mathrm{a}$ & $16.47 \mathrm{a}$ & $18.87 \mathrm{a}$ & $18.63 \mathrm{a}$ & $17.17 b$ & $20.00 \mathrm{c}$ \\
\hline
\end{tabular}

Means followed by the same letters in a column are not significantly different according to Duncan's multiple range test $(P<0.05)$

WAIA weeks after initial application of poultry manure
The observation by Mubarak et al. (2009) however, is in line with the findings of this study, which highlighted the increase in infiltration rate of the CL compared to SCL soil, and this could be ascribed to an increase in macrospores created by soil microbial activity as a result of the application of poultry manure. Furthermore, at 9 and 12 WAIA, significant $(P<0.05)$ differences were recorded in both soil types as a result of the differences in their physical and chemical soil properties which vary greatly in their infiltration characteristics. Soil organic matters (polysaccharides, humic and fluvic acids), generated from agricultural wastes, are reported to bind soil particles together into clods and aggregates, improve structure and permeability, and subsequently influenced the infiltration rate (Gilley et al. 1986; Boyle et al. 1989). The inconsistent increase and decrease in infiltration rate with increasing application rate of poultry manure observed in both soil types in this study could be ascribed to the findings of Nwachukwu and Uzu (2008), who observed similar results using cow dung and poultry manure on similar soil types of the "Apomu series" on an alfisol (Oxic Ustropepts) in southwest Nigeria. In addition to this, the reduction in soil bulk density as a result of the added organic residue, improved structure and increase in water infiltration rate especially in CL soil type might have resulted to the optimum performance of the test crop in this study (Table 4). Khalid et al. (2014) also reported the multifarious effects of poultry manure on water infiltration rate in the soil. They affirmed and reported that water infiltration rates reduces as application of poultry manure increases, and that, it might be due to the presence of a water resistant layer of manure of about $5 \mathrm{~cm}$ thick on the soil surface. However, Martens and Frankenberger (1992) reported that the addition of animal manure and other amendments to soil greatly increased water infiltration which was directly correlated to

Table 4 Maize performance as affected by different rates of poultry manure application on two contrasting alfisols

\begin{tabular}{|c|c|c|c|c|c|c|c|}
\hline $\begin{array}{l}\text { Poultry manure } \\
(\mathrm{Mg} / \mathrm{ha})\end{array}$ & $\begin{array}{l}\text { Wet shoot } \\
\text { biomass (g) }\end{array}$ & $\begin{array}{l}\text { Dry shoot } \\
\text { biomass (g) }\end{array}$ & Cob weight (g) & $\begin{array}{l}\text { Weight of } 1000 \\
\text { grains }(\mathrm{g})\end{array}$ & $\begin{array}{l}\text { Wet grain } \\
\text { weight }(\mathrm{g})\end{array}$ & $\begin{array}{l}\text { Dry grain } \\
\text { weight/cob (g) }\end{array}$ & Yield (t/ha) \\
\hline \multicolumn{8}{|l|}{ Clay loam } \\
\hline 0 & $107.40 \mathrm{e}$ & $36.00 \mathrm{~b}$ & $150.90 \mathrm{c}$ & $70.30 \mathrm{~d}$ & $104.40 \mathrm{c}$ & $36.10 \mathrm{~d}$ & $0.38 \mathrm{~d}$ \\
\hline 2 & $143.87 \mathrm{~d}$ & $34.87 \mathrm{~b}$ & $179.40 \mathrm{c}$ & $92.23 \mathrm{c}$ & $121.40 \mathrm{c}$ & $54.63 \mathrm{c}$ & $0.90 \mathrm{c}$ \\
\hline 4 & $151.47 \mathrm{c}$ & $33.80 \mathrm{~b}$ & $279.53 b$ & $131.07 \mathrm{~b}$ & $174.03 \mathrm{~b}$ & $71.57 \mathrm{~b}$ & $2.62 b$ \\
\hline 6 & $199.50 \mathrm{a}$ & $51.63 \mathrm{a}$ & $298.97 b$ & $139.40 \mathrm{~b}$ & $177.53 b$ & $67.57 b$ & $2.82 b$ \\
\hline 8 & $167.57 \mathrm{~b}$ & $56.17 \mathrm{a}$ & $302.40 \mathrm{~b}$ & $139.97 b$ & $182.87 \mathrm{~b}$ & $71.97 b$ & $3.05 b$ \\
\hline 10 & $158.47 \mathrm{c}$ & $53.47 \mathrm{a}$ & $342.83 \mathrm{a}$ & $161.80 \mathrm{a}$ & $217.80 \mathrm{a}$ & $113.70 \mathrm{a}$ & $6.31 \mathrm{a}$ \\
\hline \multicolumn{8}{|l|}{ Sandy clay loam } \\
\hline 0 & $47.87 \mathrm{de}$ & $42.87 \mathrm{de}$ & $154.47 \mathrm{c}$ & $81.87 \mathrm{~d}$ & $107.83 \mathrm{e}$ & $54.03 \mathrm{e}$ & $0.68 \mathrm{e}$ \\
\hline 2 & $47.07 \mathrm{e}$ & $41.07 \mathrm{e}$ & $172.63 \mathrm{c}$ & $107.27 \mathrm{c}$ & $121.00 \mathrm{~d}$ & $59.97 \mathrm{de}$ & $1.11 \mathrm{~d}$ \\
\hline 4 & $52.17 \mathrm{~cd}$ & $47.17 \mathrm{~cd}$ & $272.67 b$ & $124.83 b$ & $166.13 \mathrm{c}$ & $68.13 \mathrm{~cd}$ & $2.32 \mathrm{c}$ \\
\hline 6 & $64.93 \mathrm{a}$ & $59.53 \mathrm{a}$ & $302.03 \mathrm{ab}$ & $147.03 \mathrm{a}$ & $180.07 b$ & $76.10 \mathrm{bc}$ & $3.38 b$ \\
\hline 8 & $59.53 b$ & $54.93 b$ & $303.93 b$ & $148.57 \mathrm{a}$ & $185.37 \mathrm{~b}$ & $81.13 b$ & $3.66 \mathrm{~b}$ \\
\hline 10 & $53.40 \mathrm{c}$ & $48.40 \mathrm{c}$ & $328.53 a$ & $152.87 \mathrm{a}$ & $203.97 \mathrm{a}$ & $96.47 \mathrm{a}$ & $4.84 \mathrm{a}$ \\
\hline
\end{tabular}

Means followed by the same letters in a column are not significantly different according to Duncan's multiple range test $(P>0.05)$ 


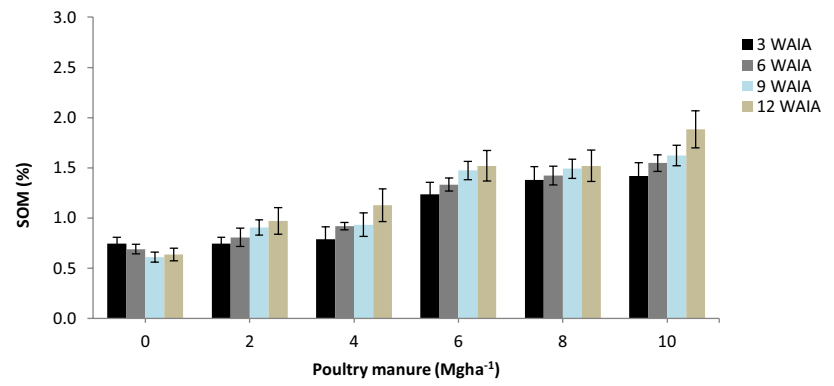

Fig. 1 Soil organic matter in a sandy clay loam as affected by poultry manure application rates $(0,2,4,6,8$, and $10 \mathrm{Mg} / \mathrm{ha})$. Error bars correspond to the standard deviation and compared to the control $(0$ $\mathrm{Mg} / \mathrm{ha})(P<0.05)$; SOM soil organic matter, WAIA weeks after initial application of poultry manure

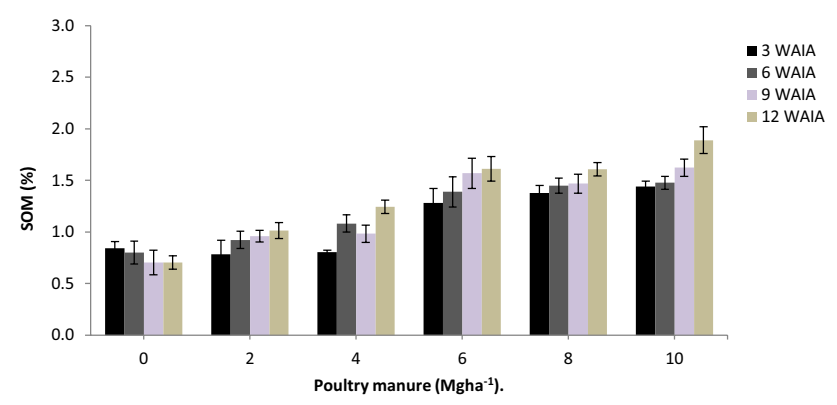

Fig. 2 Soil organic matter in a clay loam as affected by poultry manure application rates $(0,2,4,6,8$, and $10 \mathrm{Mg} / \mathrm{ha})$. Error bars correspond to the standard deviation and compared to the control $(0$ $\mathrm{Mg} / \mathrm{ha})(P<0.05)$; SOM soil organic matter, WAIA weeks after initial application of poultry manure

the amount of organic material applied. Busari et al. (2009) inferred that application of ten tonnes per hectare (10 t/ha) of poultry manure only improved the tendency and potential of soil to transmit water sorptivity under unsaturated condition. This study established that $10 \mathrm{Mg} / \mathrm{ha}$ poultry manure recorded the highest values of CIR in the CL soil type while the same manure application rate recorded the lowest values of CIR for SCL soil type.

\section{Soil organic matter as affected by poultry manure application rates}

The test soils used for this study were physically degraded and needed being improvement through the application of poultry manure. Findings from this study affirmed the importance of organic matter in acting as nutrient sink for soils and also in the improvement and stabilization of soil structure and physical properties (Okoye 1995). Figures 1 and 2 show data on relationship between manure application rates and SOM at different weeks after initial application on different soil types. Poultry manure was applied at the start of the study, then, thereafter at 4 and 8 weeks after initial application (WAIA) at each site. At all period of determination, linear increasing trends of SOM on both soil types were observed. Soil organic matter contents increased with increasing rate of poultry manure significantly $(P<0.05)$ compared to the control. The highest SOM recorded was noticed when $10 \mathrm{Mg} / \mathrm{ha}$ of poultry manure was applied and was significantly $(P<0.05)$ different at every period of determination from other application rates in both soils. For the six periods in sandy clay loam, the mean values for SOM were $0.67,1.89,2.20,2.67,3.24$, and $3.75 \%$ for 0,2 , $4,6,8$, and $10 \mathrm{Mg} / \mathrm{ha}$, respectively; while for clay loam, the mean values for SOM were $0.80,2.49,2.80,3.27,3.87$, and $4.35 \%$ for $0,2,4,6,8$, and $10 \mathrm{Mg} / \mathrm{ha}$. Our findings revealed that addition of organic manure such as poultry is essential to stabilize soil against physical degradation regardless of soil types. Because, the difficulty of organic matter retention under tropical conditions calls for sustainable organic matter contents in tropical alfisol to sustain its physical, chemi$\mathrm{cal}$, and biological components and nutrient status. It can be inferred that the application rate of $10 \mathrm{Mg} /$ ha poultry manure consistently increased soil organic matter significantly in both soil types, which led to an expected increase in SOM regardless of differences in soil types. This is consistent with the findings of several workers (Babalola et al. 2012) who reported an increase in SOM with increasing rate of poultry manure under similar soil types using yam, okra, and tomatoes as test crops.

\section{Effect of poultry manure application rates on maize performance}

Poultry manure in this study significantly increased yield parameters of maize such as fresh shoot biomass, dry shoot biomass, cob weight, dry grain weight, wet grain weight, and 1000 grain weight regardless of differences in soil types. Table 4 shows data on fresh shoot biomass and dry shoot biomass as influenced by application of poultry manure. An increasing linear trend was observed under manure rate of $4-10 \mathrm{Mg} / \mathrm{ha}$ which increased maize shoot biomass significantly $(P<0.05)$. In the soil types under study, application rate of $6 \mathrm{Mg} / \mathrm{ha}$ manure recorded highest fresh shoot biomass, while $8 \mathrm{Mg} / \mathrm{ha}$ increased dry shoot biomass in both soil types. The data in Table 4 also showed that cob and grain yield were significantly $(P<0.05)$ increased by poultry manure relative to the control. This increase could be ascribed to the availability of more nutrients by poultry manure throughout the growing season. The increases are attributed to improvement in soil properties such as reduction in bulk density, increase in both infiltration rates and SOM indicating improved aggregate stability, nutrient release, and moisture availability. Compared to the control (0 Mg/ha), manure rate at $2 \mathrm{Mg} / \mathrm{ha}, 4 \mathrm{Mg} / \mathrm{ha}, 6 \mathrm{Mg} / \mathrm{ha}, 8 \mathrm{Mg}$ / 
ha, and $10 \mathrm{Mg} / \mathrm{ha}$ increased cob weight by $19,85,98,100$, and $127 \%$ in clay loam soil type, while cob weight increased by $12 \%, 77 \%, 96 \%, 97 \%$, and $113 \%$, respectively, for sandy clay loam. Further to the above, the increase recorded in the clay loam soil type in fresh and dry grain weight was $17 \%, 67 \%, 70 \%, 78 \%$, and $109 \%$ and $51 \%, 98 \%, 87 \%$, $99 \%$, and $214 \%$, respectively; while the increase recorded in fresh and dry grain weight for SCL soil type were $12 \%$, $54 \%, 67 \%, 78 \%$, and $89 \%$ and $11 \%, 26 \%, 41 \%, 50 \%$, and $79 \%$, respectively. Ultimately, $10 \mathrm{Mg} /$ ha manure application rate increased cob weight, wet grain weight, and dry grain weight/cob by $127 \%, 109 \%$, and $214 \%$, respectively, in the CL and $113 \%, 89 \%$, and $79 \%$, respectively, for SCL soil type. Mbah and Onweremadu (2009) also adduced soil aggregate stability, reduction in soil bulk density, and improved maize yield to increased SOM on ultisol in southeastern Nigeria. The authors indicated that organic amendments are effective in restoring productivity of degraded soils. Timsina (2018) and Mohamed et al. (2010) also clarified that the increase in the yield components might be associated with the release of essential micro and macro soil nutrients by the poultry manure. Similar reports were also made by several researchers including Grande et al. (2005), Yamoah et al. (2002) and Smaling et al. (2002) also reported significant increases in the maize yield biomass and other yield components with the addition of organic manure. In the study of physical and hydraulic changes in ultisols of southeastern Nigeria induced by amendment with rice mill wastes, it was observed that changes resulting from application of the amendment were capable of augmenting the soil to enhanced nutrient utilization and productivity (Yayeh and Melkamu 2017).

\section{Conclusion}

The study has shown that the use of poultry manure as organic amendment applied at $10 \mathrm{Mg} / \mathrm{ha}$ can increase soil organic matter content and improve the soil water infiltration rate, biomass and maize performance of a physically degraded alfisol regardless of soil types. However, as affirmed by this study, the influence of organic amendment such as poultry manure on soil water infiltration will vary depending on the soil type. The understanding of the relationship between the impacts of different rates of applied poultry manure on soil water infiltration, soil organic matter contents, and maize performance on different soil types is of utmost importance in providing a quality template for use and enhancing greater maize productivity in tropical alfisol. It is, therefore, concluded that organic manure such as poultry manure could be a viable tool in the improvement and stabilization of coarse textured, fragile and low in organic matter degraded alfisols. It is, therefore, recommended that poultry manure can be applied at $10 \mathrm{Mg} / \mathrm{ha}$ at intervals to improve soil physical properties, organic matter, and maize productivity significantly while reducing on-farm cost.

Open Access This article is distributed under the terms of the Creative Commons Attribution 4.0 International License (http://creativeco mmons.org/licenses/by/4.0/), which permits unrestricted use, distribution, and reproduction in any medium, provided you give appropriate credit to the original author(s) and the source, provide a link to the Creative Commons license, and indicate if changes were made.

\section{References}

Agbogidi OM, Eruotor PG, Akparobi SO (2007) Effects of crude oil levels on the growth of maize (Zea mays L.). Am J Food Technol 2(6):529-535. https://doi.org/10.3923/ajft.2007.529.535

Ande OT (2011) Soil suitability evaluation and management for cassava production in the derived savanna area of southwestern Nigeria. Int J Soil Sci 6:142-149. https://doi.org/10.3923/ ijss.2011.142.149

Anikwe MAN (2000) Amelioration of a heavy clay loam with rice husk dust and its effect on soil physical properties and maize yield. Bioresour Technol 74:169-177. https://doi.org/10.1016/S0960 -8524(00)00007-9

Babalola OA, Adesodun JK, Olasantan FO, Adekunle AF (2012) Responses of some soil biological, chemical and physical properties to short-term compost amendment. Int J Soil Sci 7:28-38. https://doi.org/10.3923/ijss.2012.28.38

Bauer A, Black AL (1992) Organic carbon effects on available water capacity of three soil textural groups. Soil Sci Soc Am J 56(1):248-254. https://doi.org/10.2136/sssaj1992.0361599500 $5600010038 \mathrm{x}$

Blake GR, Hartge KK (1986) Bulk density. In: Klute A (ed) Methods of soil analysis, part 1. Agronomy monographs, no. 9, 2nd edn. Am. Soc. of Agron. and Soil Sci., Madison

Boyle M, Frankenberger WT, Stolzy LH (1989) The influence of organic matter on soil aggregation and water infiltration. JPA 2(4):290. https://doi.org/10.2134/jpa1989.0290

Brye KR, Slaton NA, Norman RJ, Savin MC (2004) Short-term effects of poultry litter form and rate on soil bulk density and water content. Commun Soil Sci Plant Anal 35:2311-2325. https://doi. org/10.1081/LCSS-200030655

Busari MA, Salako FK, Adetunji MT, Bello NJ (2009) Effect of selected soil amendments on physical properties of an alfisol in Abeokuta South-western Nigeria. NJSS 19(1):93-99

Chaudhary AR (1993) Maize in Pakistan. Punjab Agriculture Coordination Board, Univ. Agric., Faisalabad

Duncan DB (1955) Multiple ranges and multiple F test. Biometrics II: $1-42$

Esu IE (2005) Soil characterization and mapping for food security. A Keynote Address at the 29th annual conf. of SSSN held at University of Nigeria, Abeokuta, from 6th to 10th Dec 2004

Eusufzai MK, Fujii K (2012) Effect of organic matter amendment on hydraulic and pore characteristics of a clay loam soil. Open J Soil Sci 02(04):372-381. https://doi.org/10.4236/ojss.2012.24044

Garg S, Bahla GS (2008) Phosphorus availability to maize as influenced by organic manures and fertilizer $\mathrm{P}$ associated phosphatase activity in soils. Bioresour Technol 99(13):5773-5777. https://doi. org/10.1016/j.biortech.2007.10.063

Gilley JE, Finkner SC, Varvel GE (1986) Runoff and erosion as affected by sorghum and soybean residue. Trans ASAE 29(6):1605-1610. https://doi.org/10.13031/2013.30361 
Grande JD, Karthikeyan KG, Miller PS (2005) Corn residue level and manure application timing effects on phosphorus losses in runoff. J Environ Qual 34(5):1620-1631. https://doi.org/10.2134/jeq20 04.0462

Haraldsen TK, Sveistrup TE (1994) Effects of cattle slurry and cultivation on infiltration in sandy and silty soils from northern Norway. Soil Tillage Res 29(4):307-321. https://doi.org/10.1016/01671987(94)90105-8

Jiao Y, Whalen JK, Hendershot WH (2006) No-tillage and manure applications increase aggregation and improve nutrient retention in a sandy-loam soil. Geoderma 134(1-2):24-33. https://doi. org/10.1016/j.geoderma.2005.08.012

Khalid AA, Tuffour HO, Bonsu M, Parker BQ (2014) The effects of poultry manure and NPK fertilizer on physical properties of a sandy soil in Ghana. Int J Sci Res Agric Sci 1(1):1-5. https://doi. org/10.12983/ijsras-2014-p0001-0005

Lal R (1986) Soil surface management in the tropics for intensive land use and high and sustained production. Adv Soil Sci 5:1-109. https://doi.org/10.1007/978-1-4613-8660-5_1

Lowery B, Hickey WJ, Arshad MA, Lal R (1996) Soil water parameters and soil quality. In: Doran JW, Jones AJ (eds) Methods for assessing soil quality. Madson, pp 143-155. https://doi.org/10.2136/ sssaspecpub49.c8

Martens DA, Frankenberger WT (1992) Modification of infiltration rates in an organic-amended irrigated soil. Agro J 84:707. https:// doi.org/10.2134/agronj1992.00021962008400040032x

Mbah CN, Nnej IR (2011) Effect of different crop residue management technique on selected soil properties and grain production of maize. AJAR 6(7):4149-4152. https://doi.org/10.5897/AJAR0 9.746

Mbah CN, Onweremadu EU (2009) Effect of organic and mineral fertilizer inputs on soil and maize grain yield in an acidic ultisols in Abakaliki south-eastern Nigeria. AEJA 2(1):7-12

Mohamed AM, Sekar S, Muthukrishnan P (2010) Prospects and potential of poultry manure. Asian J Plant Sci 9:172-182. https://doi. org/10.3923/ajps.2010.172.182

Mubarak AR, Omaima ER, Amal AA, Nemat EH (2009) Short-term studies on use of organic amendments for amelioration of a sandy soil. AJAR 4(7):621-627

Nelson DW, Sommers LE (1982) Total carbon, organic carbon and organic matter. In: Page AL, Miller RH, Keeney DR (eds) Methods of soil analysis, part 2. Am. Soc. of Agron, Madison, pp 539-579

Nwachukwu MA, Uzu FO (2008) Updated classification of some soil series in southwestern Nigeria\&\&\&. Niger J Agron 7:76-81

Ojeniyi SO, Amusan OA, Adekiya AO (2013) Effect of poultry manure on soil physical properties, nutrient uptake and yield of cocoyam (Xanthosoma saggitifolium) in southwest Nigeria. Am Eur J Agric Environ Sci 13(1):121-125. https://doi.org/10.5829/idosi.aejae s.2013.13.01.1861
Okoye CU (1995) SEC technology systems among small scale farmers in Anambra State, Nigeria. M.Sc. Thesis, Department of Agriculture Extension, University of Nigeria, Nsukka Nigeria

Oyonarte NA, Mateos L, Palomo MJ (2002) Infiltration variability in furrow irrigation. J Irrig Drain Eng ASCE 128:26-33. https://doi. org/10.1061/(ASCE)0733-9437(2002)128:1(26)

Pagliai M, Vignozzi N, Pellegrini S (2004) Soil structure and the effect of management practices. Soil Tillage Res 79(2):131-143. https ://doi.org/10.1016/j.still.2004.07.002

Philip JR (1969) Theory of infiltration. Adv Hydrosci 5:215-290. https ://doi.org:/10.1016/B978-1-4831-9936-8.50010-6

Richards LA (1952) Report of the subcommittee on permeability and infiltration, committee on terminology. Soil Sci Soc Am Proc 16:85-88. https://doi.org/10.2136/sssaj1952.036159950016000 $10025 \mathrm{x}$

Smaling EMA, Nandwa SW, Prestele H, Roetler R, Muchena FN (2002) Yield response of maize to fertilizers and manures under different agro-ecological condition in Kenya. Elsevier, Dordrecht. https://doi.org/10.1016/0167-8809(92)90113-P

Snedecor CW, Cochran WC (1967) Statistical methods, 6th edn. Oxford and IBL, New Delhi, pp 33-80

Soil Survey Staff (1999) Soil taxonomy. A basic system for soil classification for making and interpreting soil surveys agric handbook no. 436. USDA, Washington DC

Timsina J (2018) Can organic sources of nutrients increase crop yields to meet global food demand? Agron 8(10):214. https://doi. org/10.3390/agronomy8100214

Tisdall JM, Oades JM (1993) Organic matter and water-stable aggregates in soils. J Soil Sci 33:141-163. https://doi. org/10.1111/j.1365-2389.1982.tb01755.x

USDA (1998) Soil quality information sheet. USDA Natural resources conservation service

Yamoah CF, Bationo A, Shapiro B (2002) Trend and stability analyses of millet yields treated with fertilizer and crop residues in the Sahel. Field Crops Res 75(1):53-62. https://doi.org/10.1016/ S0378-4290(02)00008-4

Yayeh B, Melkamu A (2017) Impact of crop production inputs on soil health: a review. Asian J Plant Sci 16:109-131. https://doi. org/10.3923/ajps.2017.109.131

Zerihun D, Feyen J, Reddy JM (1996) Sensitivity analysis of furrow-irrigation performance parameters. J Irrig Drain Eng ASCE 122:49-57. https://doi.org/10.1061/ (ASCE)0733-9437(1996)122:1(49)

Publisher's Note Springer Nature remains neutral with regard to jurisdictional claims in published maps and institutional affiliations. 